\title{
INVESTIGATION ON TEACHING CRITICAL THINKING IN ENGLISH COURSE TO YOUNG ESL LEARNERS IN CHINA
}

\author{
Shu Jia \\ E PLUS, Beijing Foreign Studies University, International (China)
}

\begin{abstract}
In the past five years in China, critical thinking has been mentioned more and more, especially in English courses to young ESL learners. The lessons which are said to lead to development of critical thinking are becoming very popular among modern parents in China.

Critical thinking involves "evaluating the accuracy, credibility and worth of information and lines of reasoning. Critical thinking is reflective, logical, evidence-based, and has a purposeful quality to it" (Ormrod, 2012). Critical thinking always goes hand in hand with Bloom's Taxonomy. It is always recognized as a process that can be taught (Cole \& McGuire, 2012). But it also takes time.

In the autumn and winter of 2019, from observing English lessons given to young ESL learners in Beijing, China, the author collected the data about whether there is training or developing critical thinking in the lessons. The results show critical thinking development in lessons to different ages of students, and the differences between language skills lessons and language knowledge lessons. This study was an attempt to explore the reasons behind this phenomenon and it tried to find some practical ways to improve teaching critical thinking in ESL courses to young learners.
\end{abstract}

Keywords: Critical thinking, Bloom's taxonomy, young learners, second language.

\section{Introduction}

The importance of developing the ability for students to think critically is widely acknowledged by teachers and educators around the world at present. In $21^{\text {st }}$ Century Skills Framework, critical thinking is the first skill mentioned in the area of Learning \& Innovation skills. In the latest understanding of $21^{\text {st }}$ Century skills, critical thinking skill is for everyone. (OCED, 2008).

"Critical thinking means making reasoned judgements that are logical and well-thought out. It is a way of thinking in which you don't simply accept all arguments and conclusions you are exposed to but rather have an attitude involving questioning such arguments and conclusions. It requires wanting to see what evidence is involved to support a particular argument or conclusion (Delecce, 2014)." "Critical thinking is a fundamental skill that develops early learning exercises and activities attractive...(Florea \& Hurjui, 2015)”

In recent years in China, critical thinking has been mentioned a lot in various education fields. English courses to young ESL learners are not an exemption. Many ESL courses to young learners declared that they have covered critical thinking development in their course design. They are popular among modern parents in China.

Thinking is a complex cognitive process closely linked with the language (Florea \& Hurjui, 2015). We believe that students can benefit a lot if they are led to develop critical thinking skills in ESL class. If everything has been on the right way, the perspective would be ideal. However, how are the processes carried out in practice? The situation is not so optimistic.

The investigation in this paper is based on observation of teaching. We can see that critical thinking development for young learners is not implemented ideally as desired in every lesson. The phenomenon is analysed and the reasons are discussed.

This paper is organized as follows: Methods will be introduced in Section 2. Results and discussions will be explained in Section 3. In the last section, conclusion and future perspectives will be stated. 


\section{Methods}

The research is mainly based on quantitative analysis.

From September to December in 2019, 48 ELT lessons for young learners were observed. All the lessons were given by different teachers.

The target students in the classes observed are between 4 to 12 years old. We put them into three groups: Age 4-5, age 6-7 and age 8-12. The grouping is consistent with our course curriculum. Age 4-5 is at the stage of "Start", age 6-7 is at the stage of "Grow" and age 8-12 is at the stage of "Develop". Based on the age of the students and their learning habits, different groups of young learners are also using different series of course book to learn English as their second language.

The lessons were randomly selected. All of them were on weekends because weekends are the peak time for young learners to go to English language schools in China.

There is a common form to fill after the observation of each lesson. In the form, whether there were procedures for developing critical thinking abilities of the students is a required field. There are only two choices to fill this part, "Yes" or "No".

Based on observation records, the numbers and percentage are calculated and compared.

\section{Results and discussions}

Table 1. Percentage of lessons to different student groups in lessons with or without critical thinking.

\begin{tabular}{|l|c|c|c|c|}
\hline Target Students & \multicolumn{2}{|l|}{$\begin{array}{l}\text { Procedures for developing critical } \\
\text { thinking shown }\end{array}$} & $\begin{array}{l}\text { No Procedures for developing critical } \\
\text { thinking }\end{array}$ \\
\hline & Numbers & Percentage & Numbers & Percentage \\
\hline Age 8-12 (Develop) & 16 & $69.57 \%$ & 8 & $32.00 \%$ \\
\hline Age 6-7 (Grow) & 4 & $17.39 \%$ & 13 & $52.00 \%$ \\
\hline Age 4-5(Start) & 3 & $13.04 \%$ & 4 & $16.00 \%$ \\
\hline Total & 23 & $100 \%$ & 25 & $100 \%$ \\
\hline
\end{tabular}

Based on the statistics from Table 1, we can see that in classes where teacher tried to develop critical thinking of students, lessons to $8-12$ years-old students were the majority $(69.57 \%)$. From the highest percentage to the lowest percentage, the ranking is age 8-12 (69.57\%), age 6-7 (17.39\%) and then age 4-5 (13.04\%). While in classes where teacher didn't have teaching procedures to develop critical thinking of the students, the majority $(52 \%)$ were not those classes with the youngest students, but the middle group with students at the age of 6-7 (Table 1).

If we take a close look at constituent ratios of lessons in different age groups (see Table 2), it is indicated that in two thirds of lessons for age 8-12, teacher tried to develop critical thinking of students. But for age 6-7 students, teachers did so in only $23.53 \%$ of the lessons. The ratio is less than one third. However, in classes for age $4-5$, nearly $50 \%$ of the lessons included critical thinking development as a part of the teaching.

Table 2. Constituent ratios of lessons with or without critical thinking in different age groups of students.

\begin{tabular}{|l|c|c|c|c|c|c|c|c|c|}
\hline & \multicolumn{4}{|c|}{ Whether there were procedures for developing Critical thinking in class } \\
\hline $\begin{array}{l}\text { Target } \\
\text { Students }\end{array}$ & \multicolumn{3}{|c|}{$\begin{array}{c}\text { Age 8-12 } \\
\text { (Develop) }\end{array}$} & \multicolumn{3}{c|}{$\begin{array}{c}\text { Age 6-7 } \\
\text { (Grow) }\end{array}$} & \multicolumn{3}{c|}{$\begin{array}{c}\text { Age 4-5 } \\
\text { (Start) }\end{array}$} \\
\hline Yes/No & Yes & No & Total & Yes & No & Total & Yes & No & Total \\
\hline Numbers & 16 & 8 & 24 & 4 & 13 & 17 & 3 & 4 & 7 \\
\hline Percentage & $66.67 \%$ & $33.33 \%$ & $100 \%$ & $23.53 \%$ & $76.47 \%$ & $100 \%$ & $42.86 \%$ & $57.14 \%$ & $100 \%$ \\
\hline
\end{tabular}

In Bloom's taxonomy, the highest levels require critical thinking (Cole \& McGuire, 2012). That is why it is always believed that the younger the students are, the more difficult it is to implement critical thinking training in class. But why is it that the result shows us that the lowest percentage comes from the middle age group in the three groups of students, but not the youngest?

Further exploration might answer this question (See Table 3). Among the four lessons which implemented critical thinking development in age 6-7 group, three of them are reading skill lessons. Only one is language knowledge lessons which emphasizes more on vocabulary, grammar and pronunciation. While among the thirteen lessons which showed no procedures for developing critical thinking, ten of them are language knowledge lessons. In the reading skill lessons, teachers were using leveled readers. It seemed that by using literature in ELS classes, teachers have more tendency to lead young learners to think critically. It "makes people think and that means teachers as well as children" (Ellison, 2010). 
Table 3. Comparison between different lesson types in group of Age6-7.

\begin{tabular}{|l|c|c|c|c|c|c|c|}
\hline $\begin{array}{l}\text { Target } \\
\text { Students }\end{array}$ & & \multicolumn{2}{|c|}{$\begin{array}{l}\text { Procedures for developing critical } \\
\text { thinking shown }\end{array}$} & \multicolumn{2}{|c|}{$\begin{array}{l}\text { No Procedures for developing } \\
\text { critical thinking }\end{array}$} \\
\hline $\begin{array}{c}\text { Age 6-7 } \\
\text { (Grow) }\end{array}$ & $\begin{array}{c}\text { Lesson } \\
\text { types }\end{array}$ & $\begin{array}{c}\text { Skills } \\
\text { lesson }\end{array}$ & $\begin{array}{c}\text { Knowledge } \\
\text { lesson }\end{array}$ & Total & $\begin{array}{c}\text { Skills } \\
\text { lesson }\end{array}$ & $\begin{array}{c}\text { Knowledge } \\
\text { lesson }\end{array}$ & Total \\
\cline { 2 - 8 } & Numbers & 3 & 1 & 4 & 3 & 10 & 13 \\
\cline { 2 - 8 } & Percentage & $75 \%$ & $25 \%$ & $100 \%$ & $23.08 \%$ & $76.92 \%$ & $100 \%$ \\
\hline
\end{tabular}

Every time we talk about critical thinking, Bloom's Taxonomy can never be ignored. They always go hand in hand. Critical thinking can be seen as a line-through of Bloom's Taxonomy. There are six levels in Bloom's Taxonomy (Bloom, 1956). The bottom level "Remember"is usually recognized as LOTS (Lower-Order Thinking Skills). However, to remember something may also inspire you to recall or identify, to analyze or interpret, to compare, match and so forth, which also involves critical thinking. Therefore, to implement development of critical thinking in knowledge lessons is achievable and practical.

Critical thinking is a skill, but it does not mean only in language skills lessons can we help students to develop it. While learning grammar rules, word-building or phonics, students can also develop their critical thinking.

Using literature in ESL classes has a positive effect on young learners' critical thinking development, but it still needs teachers' efforts. "Young learners will engage in critical thinking and purposeful decision-making when they feel affectively involved or connected to a problem or decision point(Cole \& McGuire, 2012)." To make education more thinking-centred, teachers need to better prepare themselves (Ellison, 2010).

\section{Conclusion}

Educators emphasized a lot on critical thinking for its importance in the process of growth and development of children. Critical thinking is a process that can be taught (Cole \& McGuire, 2012). But children can only be taught to be creative with rich environments provided, where they are able to explore and can ask questions, make hypothesis and develop their thinking (French, 2007) .

To develop the critical thinking of young learners has already been on the schedule of ESL course design in China. But the awareness of its significance is not enough, whether and how teachers implement critical thinking into their lessons is also an important and crucial factor to the development of critical thinking of children. Differences among teachers are obvious. Some teachers have included this in their lesson plans, some may have the awareness but do not know what to do to engage young learners in critical thinking. Meanwhile, there are some teachers who may need training to better understand what critical thinking is and then to make it a part of their lessons.

Critical thinking can be taught. But it takes time. Also it is a complicated project. It is a process of cooperation which requires efforts from educators, course designers, teachers, parents and students themselves. Young learners may need more support from teachers and parents. Their interests can be aroused, and their enthusiasm and potential can be inspired if we use the right and appropriate ways.

Development of critical thinking is not only a slogan. There are lots to be considered and more efforts are needed to make it play the right role in children's learning process. "Helping children to become better thinkers does not mean a huge change in what we change. It means a change in the way we think about it (Ellison, 2010)."Only if the teachers are on the right path, can children become critical thinkers.

\section{References}

Bloom, B.S. (Ed) (1956). Taxonomy of Educational Objectives, Handbook I: Cognitive Domain. New York: Longman.

Cole, B., \& Margit, M. (2012) Real-World Problems: Engaging Young Learners in Critical Thinking. Social Studies and the Young learner 24(4) 15-17

Delecce, T., (2014) "What is Critical Thinking? - Definition, Skills and Meaning". Retrieved from: https://study.com/academy/lesson/what-is-critical-thinking-definition-skills-meaning.html 
Ellison, M.(2010). Make them think! Using literature in the primary English language classroom to develop critical thinking skills. Retrieved from https://ler.letras.up.pt/uploads/ficheiros/8664.pdf

Florea, N.M., \& Hurjui, E.(2015). Critical thinking in elementary school children. Procedia - Social and Behavioral Sciences 180(2015) 565-572

French, G. (2007). Children's early learning and development: A research paper. Retrieved from: https://www.curriculumonline.ie/getmedia/88b84797-73d5-4249-aa3b0f861796c448/ECSEC05 Exec2 Eng.pdf

Organisation for Economic Co-operation and Development (OCED). (2008). 21 Century Skills: How can you prepare students for the new Global Economy? Retrieved from: https://www.oecd.org/site/educeri21st/40756908.pdf

Ormrod, E.D., (2012) Human Learning, $6^{\text {th }}$ ed. Boston: Pearson 